\title{
Trophic degradation predispositions and intensity in a high- flow, silted reservoir
}

\author{
Lilianna Bartoszek ${ }^{\text {Corresp., } 1}$, Małgorzata Miąsik ${ }^{1}$, Piotr Koszelnik $^{1}$ \\ ${ }^{1}$ Department of Environmental Engineering and Chemistry, Faculty of Civil and Environmental Engineering and Architecture, Rzeszów University of \\ Technology, Rzeszów, Poland \\ Corresponding Author: Lilianna Bartoszek \\ Email address: bartom@prz.edu.pl
}

The objective of the work was to demonstrate the relationship between the natural environmental characteristics of a reservoir and its catchment and severity of trophic degradation. The shallow, highly-silted Rzeszów Reservoir (SE Poland) was the object of study. The impact on degradation of internal supply from accumulated bottom sediments was also assessed, using water and sediment sampled in 2013 and 2014. A high value for trophic state was identified for the reservoir on the basis of TSI indexes, while assessed natural resilience to degradation and analysis of the catchment as a supplier of biogenic and organic matter both indicate high susceptibility to cultural eutrophication. Obtained values for equilibrium phosphate concentrations under anoxic conditions (EPC-0) point to the possibility of a more-intensive process of internal supply in phosphorus. However, the presence of sediments poor in organic matter suggest no major threat of ongoing eutrophication. Desludging and/or dredging are likely to entail elimination from the ecosystem of a large part of the pollutants accumulated in sediments, as well as the internal supply of phosphate to the water column. However, as external sources are responsible for the advanced degradation of Rzeszów Reservoir, any attempts at reclamation within the water will fail to yield persistent effects if appropriate protective procedures in the catchment are not implemented. 
2 Trophic degradation predispositions and intensity in a 3 high-flow, silted reservoir

4

5

8

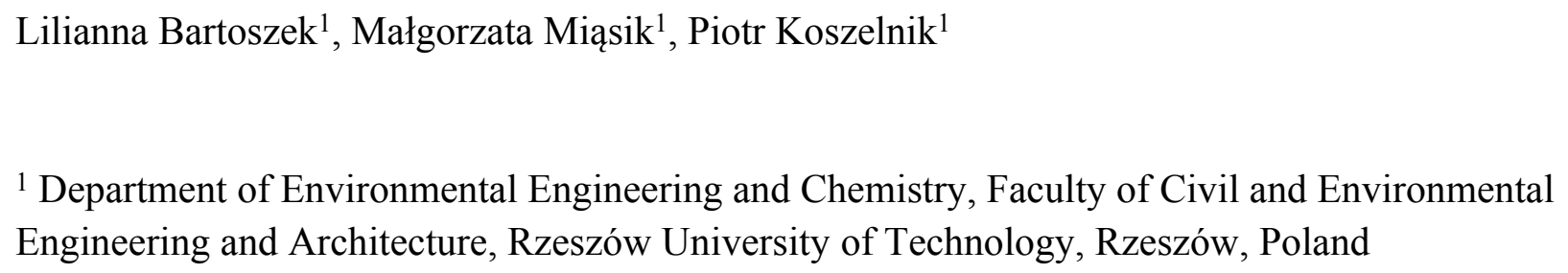

\section{Abstract}

The objective of the work was to demonstrate the relationship between the natural environmental characteristics of a reservoir and its catchment and severity of trophic degradation. The shallow, highly-silted Rzeszów Reservoir (SE Poland) was the object of study. The impact on degradation of internal supply from accumulated bottom sediments was also assessed, using water and sediment sampled in 2013 and 2014. A high value for trophic state was identified for the reservoir on the basis of TSI indexes, while assessed natural resilience to degradation and analysis of the catchment as a supplier of biogenic and organic matter both indicate high susceptibility to cultural eutrophication. Obtained values for equilibrium phosphate concentrations under anoxic conditions (EPC-0) point to the possibility of a more-intensive process of internal supply in phosphorus. However, the presence of sediments poor in organic matter suggest no major threat of ongoing eutrophication. Desludging and/or dredging are likely to entail elimination from the ecosystem of a large part of the pollutants accumulated in sediments, as well as the internal supply of phosphate to the water column. However, as external sources are responsible for the advanced degradation of Rzeszów Reservoir, any attempts at reclamation within the water will fail to yield persistent effects if appropriate protective procedures in the catchment are not implemented.

\section{Introduction}

The primary function of small reservoirs is to retain water and balance flow in the river below. The main economic problem characteristic for waters of this size is their tendency to experience ongoing deterioration in water quality, as associated with a rapid reduction in capacity and therefore declining resilience to supplied contaminants. A marked process of silting and 
40

41

42

43

44

45

46

47

48

49

50

51

52

53

54

55

56

57

58

59

60

61

62

63

64

65

66

67

68

69

70

71

72

73

74

75

76

77

78

79

shallowing is also associated with intensified sediment resuspension that combines with turbidity to encourage secondary pollution with substances accumulated in bottom sediments (Cyr, McCabe \& Nürnberg, 2009; Tammeorg et al., 2016; Lee et al., 2019).

These problems reflect both sedimentation of suspended inflowing material and allochthonous river-sediment transport and trail along the reservoir bottom, as well as the production of matter within the reservoir via eutrophication (Michalec \& Tarnawski, 2008; Dunalska, 2011; Wiatkowski \& Rosik-Dulewska, 2016). Such factors responsible for degradation of the ecosystem often interact with increased strength due to a reservoir being located improperly. At the design stage the impact of a catchment is often overlooked, and most especially the relationship between the area of the latter and the surface area of the reservoir to be constructed. In many cases, there is a further failure to fully analyze environmental characteristics in the watershed, above all geology and topography, as well as the impact of agricultural land use (Grochowska, Brzozowska \& Łopata, 2013; Koszelnik \& Gruca-Rokosz, 2013).

Given their more favorable parameters as regards morphometry (including average depth and volume) and sometimes also hydrology (e.g. hydraulic retention time), larger bodies of water prove more resilient to eutrophication than small ones (Bartoszek \& Czech, 2014; Bartoszek, 2019). Small and shallow reservoirs have what might be regarded as impaired defense mechanisms, hence the tendency for them to undergo rapid ongoing degradation. Furthermore, reservoirs located in heavily-urbanized areas are degraded much faster than those in forest, or in regions supporting agro-forestry (Gulati \& Donk, 2002; Jachniak, 2011). A significant reason for this is the supply of major loads of pollutants from both point and non-point sources (Doig et al., 2017). The occurrence of internal phosphorus supply is also of great importance for the state of a reservoir, given the way trophic degradation is intensified, while the effectiveness of introduced protective activities in the catchment is limited (North et al., 2015; Tammeorg et al., 2016; Paytan et al., 2017). The internal load can equate to as much as 45 to $89 \%$ of the external load (Nürnberg et al., 2013). Phosphorus release from sediments occurs in a bioavailable form in reservoir water (as $\mathrm{P}_{-} \mathrm{PO}_{4}{ }^{3-}$ ), with this ensuring its greater availability to phytoplankton than the $P$ from external loading introduced mainly in the form of suspended solids (Loh et al., 2013; North et al., 2015; Doig et al., 2017). Most reclamation techniques applied currently focus on eliminating the internal supply of nutrients (mainly phosphates, only rarely nitrates), or else on limiting their actual impact on the aquatic ecosystem (Gulati \& Donk, 2002; Hickey \& Gibbs, 2009; Wojciechowska, Gajewska \& Ostojski, 2017).

The parameter used to assess the capacity of bottom sediment to release $\mathrm{P}_{-} \mathrm{PO}_{4}{ }^{3-}$ is the value of the zero equilibrium phosphate concentration (EPC-0) (Wiśniewski, 1999; Bartoszek \& Koszelnik, 2016). Release of phosphate from sediment into the water column is to be expected where the near-bottom concentration of $\mathrm{P}-\mathrm{PO}_{4}{ }^{3-}$ falls below the EPC- 0 . In turn, where the value exceeds it, adsorption on to particles of sediment is to be anticipated (House, 2003; Cyr, McCabe \& Nürnberg, 2009; Dong, Yang \& Liu, 2011). The choice of the right method of restoration is in turn dependent on characteristics of the given body of water, be these morphometric, or related 
80

81

82

83

84

85

86

87

88

89

90

91

92

93

94

95

96

97

98

99

100

101

102

103

104

105

106

107

108

109

110

111

112

113

114

115

116

117

118

119

to location within the catchment and actual pollutant loads (Małecki, 2005). Differences between reservoirs (notably involving hydrological conditions and depth) ensure that not all restoration methods can be applied to each object.

The work detailed here sought to determine the relationship between natural environmental characteristics of a reservoir and its catchment area and the severity of trophic degradation. The example for study with this objective was provided by the shallow, highlysilted Rzeszów Reservoir (SE Poland), whose internal supply from accumulated bottom sediments was also assessed for its degrading impact. In general, the reservoir is able to serve as a good example of bad practice where continuous conservation and reclamation are concerned. This reflects an imperfect location and consequent ongoing degradation.

While there are no reliable data, it is estimated that there may be in excess of 16 million small bodies of water around the world (Mulligan, van Soesbergen \& Sáenz, 2020). This fact has combined with often-advanced processes of degradation, and serious problems with remediation, to ensure a continuous history of research in this area.

\section{Materials \& Methods}

\section{Study area and sampling strategy}

The researched Rzeszów Reservoir was built in 1974 through the damming of the River Wisłok at a point $63+760 \mathrm{~km}$ along its course. The reservoir is supplied by two main tributaries, i.e. the Wisłok and the Strug. Its main purpose was to allow for proper operations of the water supply to the city of Rzeszów. However, given a location on the outskirts of such a large city, a vital role as a sports and recreation lagoon is also served (Bartoszek et al., 2015). Morphometric parameters of the reservoir in 2014 are as shown in Fig. 1. Overall volume is seen to have decreased by about $40 \%$ over the 40 -year period (from $1.8 \cdot 10^{6}$ to $1.1 \cdot 10^{6} \mathrm{~m}^{3}$ ), with major silting having taken place, and indeed a gradual development of new land surface in the upper zone in particular. Attempts to restore greater usability to the reservoir were made in the years 1986-87 and 1995-97, entailing work to deepen the reservoir next to the dam, while also achieving a narrowing through partial backfill on the right part of the bank also just by the dam. In each case, some $250,000-300,000 \mathrm{~m}^{3}$ of sediment were removed (Bartoszek et al., 2015). The objective of both dredging operations was to secure an increase in rate of flow, thereby reducing sedimentation. Unfortunately, this restoration did not bring the expected results. After just 7 years, sedimentation had exceeded the amount removed previously (Madeyski, Michalec \& Tarnawski, 2008).

As the watershed of Rzeszów Reservoir is of $2025 \mathrm{~km}^{2}$, this represents a considerable proportion of the entire Podkarpackie voivodship (province-region of Poland). The difference in water level between the main supply of the Wisłok at the source and the mouth of the reservoir is $616 \mathrm{~m}$. The Wisłok flows through foothill areas that are largely agricultural, though the upper parts are forested, while the middle part does also have industrial centers (glassworks, tanneries and refineries) along its course. The catchment of the smaller tributary, the Strug stream, is predominantly agricultural, with traditional fragmented patches of farmland typically associated 
120

121

122

123

124

125

126

127

128

129

130

131

132

133

134

135

136

137

138

139

140

141

142

143

144

145

146

147

148

149

150

151

152

153

154

155

156

157

158

159

with a high-density population. The share of individual land-use forms in the catchment is arable land $-55 \%$, built-up areas $-10 \%$, forest areas $-20 \%$, wasteland and meadows $-15 \%$. The reservoir can thus be said to be under strong anthropopressure associated with local agriculture that causes severe erosion of the land. Wastes of various kinds are also deposited in the area, and other kinds of diffuse pollution occur (Koszelnik, 2007; Gruca-Rokosz, Tomaszek \& Koszelnik, 2009; Report RP., 2016).

Water and sediment samples were taken from three sites along the axis of the reservoir (Fig. 1), four times in the May-September period of 2013, and five times in the same period of 2014.

Rzeszów Reservoir's natural susceptibility to degradation was evaluated on the basis of two procedures (described in more detail in Supplemental file 1):

1. Resilience in the face of degradation was assessed by modifying the so-called Lake Quality Assessment Scheme (Bajkiewicz-Grabowska, 1987, 2010) in line with the status of the reservoir as an artificial body of water.

2. Assessment of catchment-area impacts relating to the supply of the reservoir in biogenic and organic matter was carried out in line with the system proposed by BajkiewiczGrabowska (1987, 2010), as well as Markowski \& Kwidzińska (2015).

\section{Water analysis}

Temperature $\left(\mathrm{T}_{\mathrm{w}}\right)$, $\mathrm{pH}$ and dissolved oxygen $\left(\mathrm{O}_{2}\right)$ were measured in situ with a Hach Lange HQ40D meter. Total nitrogen (TN) was determined using a TOC-VCPN analyzer (Shimadzu), phosphatephosphorus ( $\mathrm{P}-\mathrm{PO}_{4}{ }^{3-}$ ) and chlorophyll $a$ spectrophotometrically (Aquamate, Thermo Spectronic) using filtered samples of water following reaction with ammonium molybdate and hot extraction with ethanol, respectively. Total phosphorus (TP) was determined analogously, but in non-filtered and mineralized $\left(\mathrm{H}_{2} \mathrm{SO}_{4}\right.$ and peroxodisulfate) samples of water. Trophic status of the water was approximated by reference to Carlson Indexes $\left(\mathrm{TSI}_{\mathrm{TP}}\right.$ and $\mathrm{TSI}_{\mathrm{Chla}}$ ) (Carlson, 1977).

\section{Sediment analysis}

Sediment samples (from the 0-5 cm layer) were dried and further assessed for Loss-on-Ignition (LOI) at $550^{\circ} \mathrm{C}$ for four hours (4h), with this construed as organic matter content (OM). For the analysis of P fractionation in sediment, the SMT (Standards, Measurements and Testing) method was customized (Pardo, Rauret \& Lopez-Sanchez, 2004). The fractions of P obtained were nonapatite, inorganic (NAIP, associated with oxides and hydroxides of Al, Fe and Mn), apatite (AP, associated with $\mathrm{Ca}$ ) and organic (OP). Following microwave mineralization $\left(\mathrm{HNO}_{3}, 2-4.5 \mathrm{MPa}\right)$, TP was measured as above, with quantitative determinations for Fe, $\mathrm{Ca}, \mathrm{Al}$ and $\mathrm{Mn}$ made using an ICP spectrometer (Integra, GBC).

\section{Measuring of the EPC-0}

EPC-0 values were measured in aerobic and anoxic conditions in association with $\mathrm{P}_{-} \mathrm{PO}_{4}{ }^{3-}$ concentrations in above-surface water in the range 0.0 to $1.3 \mathrm{mgP} \mathrm{dm}^{-3}\left(\right.$ as $\left.\mathrm{KH}_{2} \mathrm{PO}_{4}\right)$. For this purpose, six intact sediment cores were collected into Plexiglas tubes (from the thin-upper layer 
160

161

162

163

164

165

166

167

168

169

170

171

172

173

174

175

176

177

178

179

180

181

182

183

184

185

186

187

188

189

190

191

192

193

194

195

196

197

198

199

of 0-5 cm). Natural water was decanted and replaced by reservoir water diluted 1:10 with distilled water, this then being deoxygenated using anhydrous sodium sulfate (IV), in order to generate anoxic conditions. Sediments were re-suspended for 10 minutes by mixing an approx. 1 $\mathrm{cm}$ layer using a mechanical mixing device (approx. 150 rotations per minute). Reactors were then left in a dark, cool place for re-sedimentation of suspension over a period of $110 \mathrm{~min}$. After $2 \mathrm{~h}$ of exposure, concentrations of $\mathrm{P}_{-} \mathrm{PO}_{4}{ }^{3-}$ were measured in the water. The EPC-0 was determined as the zero of a linear function of $\mathrm{Cp}-\mathrm{Ck}=\mathrm{f}(\mathrm{Cp})$, (where $\mathrm{Cp}-\mathrm{P}_{-} \mathrm{PO}_{4}{ }^{3-}$ is concentration prior to exposure and $\mathrm{Ck}-\mathrm{P}_{-} \mathrm{PO}_{4}{ }^{3-}$ concentration after exposure) (Wiśniewski, 1999; Bartoszek \& Koszelnik, 2016). The potential phosphorus load [mgP· $\left.\mathrm{m}^{-2} \mathrm{~d}^{-1}\right]$ releasable from bottom sediments under given conditions was calculated on the basis of the amount of $\mathrm{P}$ $\mathrm{PO}_{4}{ }^{3-}$ released in ex situ tests, with account taken of the average concentration of this form in the reservoir water throughout the research period.

\section{Results \& Discussion}

\section{Natural susceptibility to degradation}

The parameters of Rzeszów Reservoir affecting natural resilience to degradation are as summarized in Table 1 . The Reservoir is assigned to the $4^{\text {th }}$ (or lowest) category of resilience, given its unfavorable hydrological and morphometric parameters, which in fact ensure an almost total lack of resilience to negative impacts from the catchment area. This mainly reflects limited depth and volume of water, and hence a polymictic character of the ecosystem. Equally, the reservoir is characterized negatively by parameters such as the ratio of the active sediment layer surface to the volume of the epilimnion, and Schindler's ratio. In the case of shallow unstratified reservoirs, bottom sediments across the entire area affect metabolism within the ecosystem as a whole. The catchment area of the reservoir is of $2060.7 \mathrm{~km}^{2}$, while reservoir volume is just 1.10 $\mathrm{Mm}^{3}$, hence the high value for Schindler's ratio. The only parameter encouraging a lower risk of eutrophication progressing is the high intensity of water-exchange during the year. This ensures the prevalence of river conditions unfavorable to the development of plankton.

Beyond the morphometric parameters of Rzeszów Reservoir, the geology and nature of the catchment also do much to encourage degradation. Features as summarized in Table 2 speak for assignment to susceptibility category 4 (the worst), denoting a high probability of supply of organic and inorganic matter and nutrients. The probability that critical loads of pollution will be reached is enhanced by the large catchment area in relation to the surface area of the body of water (Ohle's coefficient), but also by the nature of the flow through the reservoir, the presence of pastureland and agricultural management, and the presence of mountainous terrain conducive to erosion of either natural and anthropogenic origin.

Given assignment to category 4 where both resilience and susceptibility are concerned, it is clear that the setup as regards type of reservoir and type of catchment is maximally negative, and inevitably associated with a considerable risk of eutrophication progressing, due to the adverse natural conditions. 
200 Trophic state and the role of sediments as an internal source of phosphorus

201 Advanced eutrophication of the waters under study is indicated by values calculated for the 202 Carlson trophic index (Table 3). The calculated TSI ${ }_{\mathrm{TP}}$ is indicative of hypertrophy, while the 203 TSI $_{\text {Chla }}$ suggests eutrophic status. Thanks to flow through the reservoir, a part of the phosphorus 204 load is discharged and does not therefore participate in internal processes. This accounts for the 205 above discrepancy between trophic statuses determined by reference to trophic indices for the 206 substrate as opposed to the product. Rzeszów Reservoir resembles other bodies of water 207 recording high values for trophic status (Gruca-Rokosz, Bartoszek \& Koszelnik, 2017) in 208 experiencing summer-season oxygen saturation associated with insolation-influenced 209 photosynthesis. However, the related phenomenon of water undergoing alkalization (Bartoszek 210 et al., 2018) has not been detected (Figs. 2A-B). Concentrations of the substrates nitrogen and 211 phosphorus in reservoir water were relatively high, amounting to 1.46 and $0.171 \mathrm{mg} \cdot \mathrm{dm}^{-3}$ 212 respectively, on average. Mean values for the $\mathrm{N}: \mathrm{P}$ mass ratio below 10:1 indicate that nitrogen is 213 usually present at concentrations limiting the reservoir's internal production of OM (Galvez214 Cloutier \& Sanchez, 2007; Hou et al., 2013). A reduction of the ratio of nitrogen to phosphorus 215 (N:P) in water, and therefore stimulation of cyanobacterial bloom, can occur due to the release of 216 phosphates accumulated in sediments (Orihel et al., 2015). It was usual for higher Chla concentrations to be observed in the region of the dam where water flows most slowly (Fig. 2C).

220

221

222

223

224

225

226

227

228

229

230

231

232

233

234

235

236

237

238

239
The abundance of phosphorus compounds in a water depends, not only on the external load supplied, but also on the capacity for internal supply by way of the release of phosphates from bottom sediments under anoxic conditions (Nikolai \& Dzialowski, 2014; Bartoszek, 2019; Lee et al., 2019). Phosphorus may be released even where conditions in the near-bottom water are aerobic, on account of the decomposition of OM deposited previously (Dondajewska, 2008; Sobczyński, 2009; Paytan et al., 2017). In the sediments studied, the EPC-0 assumed low values under aerobic conditions, but were approximately 10 times higher in circumstances of anoxia (Table 4). At $0.005-0.108 \mathrm{mgP} \cdot \mathrm{dm}^{-3}$, concentrations of $\mathrm{P}_{-\mathrm{PO}_{4}}{ }^{3-}$ in the waters studied were not high at any time during the study period. Only twice was the value for the EPC-0 in aerobic conditions exceeded - at site 1 (near the inlet), with 0.073 and $0.108 \mathrm{mgP} \cdot \mathrm{dm}^{-3}$ reported (Figs. $3 \mathrm{~A}-\mathrm{C}$ ). On other dates, release of phosphate from sediment into the near-bottom water was able to occur at the sites studied, with resources depleted by phytoplankton and macrophytes augmented in this way. Hydrobiological analysis carried out in July 2013 showed that the largest number of phytoplankton and at the same time the most cyanobacteria were found at site 3 (near the dam). Cyanobacteria of the genera Microcystis, Oscillatoria, Aphanothece and Romeria have been observed in Rzeszów Reservoir (Bartoszek et al., 2018).

The stability of phosphorus immobilization in sediments is impacted upon by the types of chemical compound in which the element is present (Bartoszek \& Tomaszek, 2011; Dong, Yang \& Liu, 2011; Loh et al., 2013). Phosphorus fractionation studies demonstrate that it is the NAIP fraction within TP that is largest (42.5\% on average). This reflects combination with $\mathrm{Fe}, \mathrm{Al}$ and Mn (Table 5). The AP fraction, denoting an association with $\mathrm{Ca}$ and a status as least mobile, was at $34.3 \%$ on average. The smallest share was taken by the organic fraction - OP (average

Peer) reviewing PDF | (2020:01:44688:1:0:NEW 27 Apr 2020) 
$24021.6 \%$ ). The average content of mobile phosphorus (NAIP + OP) thus reached $64.1 \%$. For 241 comparison, the NAIP + OP fraction in the bottom sediments of France's Bort-les-Orgues dam 242 reservoir heavily exposed to anthropogenic influences was found to exceed $80 \%$, including on 243 the basis of NAIP accounting for 59\% of TP (Ruban et al., 2001). In contrast, in the sediment of 244 Poland's Solina Reservoir, the contribution made by NAIP was of only $23.8 \%$, while NAIP + OP 245 stood at $57.7 \%$ on average (Bartoszek \& Tomaszek, 2011). Solina Reservoir is located in

246

247

248

249

250

251

252

253

254

255

256

257

258

259

260

261

262

263

264

265

266

267

268

269

270

271

272

273

274

275

276

277

278 mountainous terrain that is mainly forested or comprising pastureland, while the area is only sparsely populated and developed to a limited extent, with major anthropogenic pressure therefore lacking. The studied samples from Rzeszów Reservoir in fact have a slightly lower content of phosphorus and OM than those from Solina, though they are characterized by approximately 1.5-2 fold lower concentrations of $\mathrm{Fe}$ and $\mathrm{Al}$, as well as concentrations of $\mathrm{Mn}$ only one-fourth as high (Bartoszek, Tomaszek \& Lechowicz, 2015). In contrast, they contained more $\mathrm{Ca}$ (approx. 2.5 times), perhaps reflecting the catchment's mainly agricultural land use. A low value for EPC-0 in the sediments of Rzeszów Reservoir, especially under aerobic conditions, results from the typical mineral nature of the deposits (OM of less than $8 \%$ ) and the relatively low content of phosphorus with good oxygenation at the interface between bottom sediments and overlying water. By comparison, EPC-0 values in Solina Reservoir ranged from 0.007 to $0.057 \mathrm{mgP} \cdot \mathrm{dm}^{-3}$ in aerobic conditions and from 0.103 to $0.169 \mathrm{mgP} \cdot \mathrm{dm}^{-3}$ under anoxia (Bartoszek \& Koszelnik, 2016). In turn, in a small, heavily-degraded reservoir (at Nowa Wieś, SE Poland), EPC-0 values were 0.33 and $4.67 \mathrm{mgP} \cdot \mathrm{dm}^{-3}$ (in aerobic and anoxic conditions respectively) (Bartoszek, 2019). EPC-0 values determined around the world under aerobic conditions, for shallow, polymictic lakes and dam reservoirs, ranged from 0.007 to 0.244 and from 0.013 to $0.3 \mathrm{mgP} \cdot \mathrm{dm}^{-3}$ (respectively) (Cyr, McCabe \& Nürnberg, 2009; Dong, Yang \& Liu, 2011).

Values for EPC-0 differed slightly among the sites studied. Under aerobic conditions EPC-0 increased along the axis of the reservoir, unlike in anoxic conditions. A similar upward trend was observed for the percentage content of the apatite fraction. The release of phosphate from sediments into the water column is mediated by different mechanisms under aerobic and anoxic conditions. Where there is good oxygenation of water it is mainly aerobic decomposition of OM that occurs, with dissolution of the apatite fraction associated with an excess of $\mathrm{CO}_{2}$. However, in the circumstances of a deficiency of oxygen, phosphates are released through anaerobic decomposition of both $\mathrm{OM}$ and sparingly soluble inorganic and inorganic-organic compounds. The lowest value for EPC-0 under anoxic conditions was that obtained for the sediments at site 2, despite the fact that it is the deposits in the transition zone of the reservoir that have highest contents of OM and TP. This site also had the sediments with the highest contents of iron, manganese, aluminum and calcium, i.e. elements directly affecting the binding of phosphorus, as well as the highest water content $\left(\mathrm{W}_{0}\right)$ (Table 5). The smallest contribution to TP of the NAIP fraction, and the largest contribution of the OP fraction also characterized the sediments at site 2 . Higher EPC- 0 values under anoxic conditions were accompanied by larger 
279 NAIP fractions in sediments, with these being more mobile in a situation of low redox potential. 280 No similar trend for the OP fraction could be observed.

281 The calculated internal phosphorus load can reach an average of $84 \mathrm{mgP} \cdot \mathrm{m}^{-2} \mathrm{~d}^{-1}$ under 282 aerobic conditions and $878 \mathrm{mgP} \cdot \mathrm{m}^{-2} \mathrm{~d}^{-1}$ under anoxic conditions (Table 6). For comparison, the 283 external phosphorus load estimated on the basis of data on the development of the catchment 284 area, i.e. the share of arable land, built-up areas, forests and wastelands, as well as literature run285 off coefficients was $266.8 \mathrm{mgP} \cdot \mathrm{m}^{-2} \mathrm{~d}^{-1}$ (Report RP., 2016). However, this does not take account 286 of actual loads from anthropogenic sources (e.g. industry and services) introduced into the 287 reservoir via tributaries.

Nevertheless, the external load estimated for Rzeszów Reservoir was higher than the calculated internal load under aerobic conditions, but only about one-third as high as under

290

291

292

293

294

295

296

297

298

299

300

301

302

303

304

305

306

307

308

309

310

311

312

313

314

315

316

317

318 anoxic conditions. The calculated internal phosphorus loads represent possible release in extreme environmental conditions, with resuspension of the surface sediment layer occurring frequently (ex situ for 10 min during a 2-hour test) and oxygen lacking around the clock (under anoxic conditions). In addition, steady phosphate uptake by phytoplankton would have to occur to reduce concentrations in water to the initial level (the average concentration of $\mathrm{P}_{-} \mathrm{PO}_{4}{ }^{3-}$ in reservoir water included in the calculations).

Complete oxygen depletion may occur periodically during a hot and windless summer, but rather in reservoirs with significant sediment enrichment in organic matter and/or at slow water flow (Bartoszek, 2019). The internal load values obtained for lake sediments are much lower $\left(0.16-2.91\right.$ and $0.58-27.3 \mathrm{mgP} \cdot \mathrm{m}^{-2} \mathrm{~d}^{-1}$, aerobic and anoxic respectively). However, the values for internal phosphorus load under anoxic conditions are 4-13 times greater than under aerobic conditions (North et al., 2015; Matisoff et al., 2016). Research to date has shown that 1 to $50 \mathrm{mgP} \cdot \mathrm{m}^{-2} \mathrm{~d}^{-1}$ of $\mathrm{P}$ can be released from sediment in eutrophic and hypertrophic lakes and reservoirs (Carter \& Dzialowski, 2012; Nikolai \& Dzialowski, 2014). Due to the different methods and conditions of measurement, it is impossible to compare the results obtained with those of other researchers, who for example did not consider re-suspension of sediment during core-incubation. Researching the sediments of 17 reservoirs in the USA, Carter \& Dzialowski (2012) noted that P-release from deposits was usually more intensive in waters that had a higher percentage of arable land in their catchments. Both the budget of $\mathrm{P}$ in overlying water and the quantity of release are determined by the inflow of nutrients from external sources (Nikolai \& Dzialowski, 2014), which can limit real internal supply significantly in high-flow reservoirs.

Due to intensive mixing and good oxygenation of water $\left(6.9-10.8 \mathrm{mg} \cdot \mathrm{dm}^{-3}\right)$, Rzeszów Reservoir has less-favorable conditions for both phosphorus release from sediments and abundant phytoplankton development. However, considerable shallowing and silting increases the possibility of deposit resuspension, which involves an increased area of exchange of substances between sediment and water. One of the undesirable effects of climate change in the temperate zone is the occurrence of ever-longer periods of high temperature in summer, and a decrease in the amount of rainfall, which can lead to periodically significant reductions in reservoir levels, with the result that flows slow and oxygen concentrations decrease. Doig et al. 
319 (2017) observed that, at an oxygen concentration of $2 \mathrm{mg} \cdot \mathrm{dm}^{-3}$, as opposed to conditions of high 320 oxygenation, there is a more marked internal supply of phosphorus from sediments, albeit one 321 that is still weaker than in anoxic conditions.

322

\section{Conclusions \& Prospects}

324 Due to strong anthropopressure and a number of exceptionally unfavorable morphometric and

325

326

327

328

329

330

331

332

333

334

335

336

337

338

339

340

341

342

343

344

345

346

347

348

349

350

351

352

353

354

355

356

357

358

environmental features, Rzeszów Reservoir is subject to a highly-advanced process of degradation that i.a. does much to limit its utility. Not only the trophic state, but most of all also the possibilities for stored-substance releases and secondary water pollution all attest to the degree to which the reservoir has degraded, most especially on account of its being located in catchment areas under strong anthropogenic influence. However, mineralization of organic matter deposited in the sediments of the reservoir takes place in an undisturbed manner, a fact that attests to its relatively low content, as well as to good oxygenation conditions prevailing in the water.

Obtained EPC- 0 values, especially for aerobic conditions, confirm a limited contribution due to internal supply within the phosphate concentration present in the water, this again reflecting good oxygenation and a relatively low content of total phosphorus in sediments. The fact that EPC-0 values are about 10 times higher under anoxic conditions indicates that, in the case of oxygen deficiency, a more-intensive process of internal supply of phosphorus can take place. However, since reservoir sediments are poor in organic matter, no major threat of furtherprogressing eutrophication is likely to be posed, especially in circumstances of strong flow.

It is the bottom sediments in the middle area of the Reservoir that appear most exposed to pollution, as highest contents for most of the parameters determined make clear. The impact exerted by the overall area of the catchment through tributaries and directly overlaps in this part of the reservoir. Closer to the reservoir, the right bank of the direct basin includes housing estates, as well as (in more recent years) an associated network of local roads. These generate pollution via surface runoff. The two attempts at modernizing the reservoir, involving only partial desludging, mainly affected the part near the dam, hence the lower concentration of pollutants in the sediments there.

If the condition of the reservoir is to be improved, desludging and dredging of the object will need to be carried out once again, but this time over a larger area. The removal of an appropriately thick layer of bottom sediment would lead to partial elimination of stored loads of phosphorus and other anthropogenic pollutants (Gulati \& Donk, 2002; Wojtkowska, 2013). Determination of that thickness of the layer of sediment needing to be removed would require testing for the accumulation of nutrients and anthropogenic substances in the vertical profile of the deposit, i.e. also in the deeper (5-10, 10-15, 15-20 cm etc.) layers; as well as an increased number of research sites. Liquidation of the shallows would also reduce overgrowth of the reservoir surface by emergent vegetation. With silting of the reservoir occurring so rapidly, action in the overall catchment would also be necessary, to reduce erosion, and hence the inflow of material containing particles of soil, rock fragments and stones.

Peer) reviewing PDF | (2020:01:44688:1:0:NEW 27 Apr 2020) 
359

360

361

362

363

364

365

366

367

368

369

370

371

372

373

374

375

376

377

378

379

380

381

382

383

384

385

386

387

388

389

390

391

392

393

394

395

396

397

398

\section{Acknowledgements}

We would like to thank our colleagues from the department laboratory for their support and help in sampling and laboratory analysis.

\section{References}

Bajkiewicz-Grabowska E. (2010), Assessment of the ecological state of lakes as proposed by the Polish Limnological Society, Limnological Review, 3-4, 105-116. DOI 10.2478/v10194-0110012-6

Bajkiewicz-Grabowska E. (1987), Evaluation of the natural susceptibility of shallow lakes to degradation, GeoJournal, 14(3), 367-371.

Bartoszek L. (2019), Degradation of small retention reservoirs - conditions, intensification, the possibility of chemical reclamation (in Polish), Oficyna Wydawnicza PRz, Rzeszów, pp 1215.

Bartoszek L., Koszelnik P., Zamorska J., Gruca-Rokosz R., Zdeb M. (2018), A preliminary study into the possibility of $\delta^{13} \mathrm{C}$ being used as a sensitive indicator of the trophic and hydrobiological status of aquatic ecosystems, Journal of Ecological Engineering, 19(6), 191198. DOI 10.12911/22998993/89829

Bartoszek L., Koszelnik P. (2016), Assessment of phosphorus retention in the bottom sediments of the Solina-Myczkowce complex of reservoirs, Rocznik Ochrona Środowiska, 18, 213-230.

Bartoszek L., Koszelnik P., Gruca-Rokosz R., Kida M. (2015), Assessment of Agricultural Use of the Bottom Sediments from Eutrophic Rzeszow Reservoir, Rocznik Ochrona Środowiska, 17, 396-409.

Bartoszek L., Tomaszek J.A., Lechowicz J.B. (2015), Differentiation of selected components in bottom sediments of Poland's Solina-Myczkowce complex of dam reservoirs. In: Tomaszek JA, Koszelnik P (eds), Progress in the Environmental Engineering. Water, Wastewater Treatment and Environmental Protection Issues. Taylor \& Francis, London, pp 11-22.

Bartoszek L., Czech D. (2014), The susceptibility of the Solina dam reservoir to degradation (in Polish), Journal of Civil Engineering, Environment and Architecture, 61(4), 35-53. DOI 10.7862/rb.2014.125

Bartoszek L., Tomaszek J.A. (2011), Analysis of the spatial distribution of phosphorus fractions in the bottom sediments of the Solina - Myczkowce dam reservoir complex. Environment Protection Engineering, 37(3), 5-15.

Carlson R.E. (1977), A trophic state index for lakes. Limnology and Oceanography 22(2), 361369. DOI 10.4319/lo.1977.22.2.0361

Carter L.D., Dzialowski A.R. (2012), Predicting sediment phosphorus release rates using landuse and water-quality data, Freshwater Science, 31(4), 1214-1222. DOI 10.1899/11-177.1

Cyr H., McCabe S.K., Nürnberg G.K. (2009), Phosphorus sorption experiments and the potential for internal phosphorus loading in littoral areas of a stratified lake, Water Research, 43, 16541666. DOI 10.1016/j.watres.2008.12.050 
399

400

401

402

403

404

405

406

407

408

409

410

411

412

413

414

415

416

417

418

419

420

421

422

423

424

425

426

427

428

429

430

431

432

433

434

435

436

437

438

Doig L.E., North R.L., Hudson J.J., Hewlett C., Lindenschmidt K.E., Liber K. (2017), Phosphorus release from sediments in a river-valley reservoir in the northern Great Plains of North America, Hydrobiologia 787, 323-339. DOI 10.1007/s10750-016-2977-2

Dondajewska R. (2008), Internal phosphorus loading from bottom sediments of a shallow preliminary reservoir, Oceanological and Hydrobiological Studies, 37(2), 89-97. DOI 10.2478/v10009-007-0043-0

Dong L., Yang Z., Liu X. (2011), Phosphorus fractions, sorption characteristics, and its release in the sediments of Baiyangdian Lake, China, Environmental Monitoring and Assessment, 179, 335-345. DOI 10.1007/s10661-010-1740-9

Dunalska J.A. (2011), Impact of morphometric and catchment variables on summer organic carbon richness in deep temperate lakes, Knowledge and Management of Aquatic Ecosystems, 403(3), 1-11. DOI 10.1051/kmae/2011043

Galvez-Cloutier R., Sanchez M. (2007), Throphic status evaluation for 154 Lakes in Quebec, Canada: Monitoring and recommendations, Water Quality Research Journal, 42(4), 252-268. DOI 10.2166/wqrj.2007.028

Grochowska J., Brzozowska R., Łopata M. (2013), Durability of changes in phosphorus compounds in water of an urban lake after application of two reclamation methods. Water Science and Technology, 68(1), 234-239. DOI 10.2166/wst.2013.249

Gruca-Rokosz R., Bartoszek L., Koszelnik P. (2017), The influence of environmental factors on the carbon dioxide flux across the water - air interface of reservoirs, south-eastern Poland, Journal of Environmental Sciences-China, 56, 290-299. DOI 10.1016/j.jes.2016.10.011

Gruca-Rokosz R., Tomaszek JA, Koszelnik P (2009), Denitrification in the sediment of a eutrophic reservoir as measured by the isotope pairing technique, Oceanological and Hydrobiological Studies, 38(1), 75-81. DOI 10.2478/v10009-009-0005-9

Gulati R.D., van Donk E. (2002), Lakes in the Netherlands, their origin, eutrophication and restoration, state-of-the-art review, Hydrobiologia 478, 73-106. DOI 10.1023/A:1021092427559

Hickey C.W., Gibbs M.M. (2009), Lake sediment phosphorus release management - Decision support and risk assessment framework, New Zealand Journal of Marine and Freshwater Research, 43, 819-856. DOI 10.1080/00288330909510043

Hou D., He J., Lü C., Sun Y., Zhang F., Otgonbayar K. (2013), Effects of environmental factors on nutrients release at sediment-water interface and assessment of trophic status for a typical shallow lake, Northwest China, The Scientific World Journal, Article ID 716342, 16 pages. DOI 10.1155/2013/716342

House W.A. (2003), Geochemical cycling of phosphorus in rivers, Applied Geochemistry, 18, 739-748. DOI 10.1016/S0883-2927(02)00158-0

Jachniak E. (2011), Loads of biogenic compounds and eutrophication of the Kozlowka reservoir (in Polish), Nauka Przyroda Technologie, 5(4), 1-9.

Koszelnik P. (2007), Atmospheric deposition as a source of nitrogen and phosphorus loads into the Rzeszów reservoir, Environment Protection Engineering, 33(2), 157-164. 
439 Koszelnik P., Gruca-Rokosz R. (2013), Determination of nitrate isotopic signature in waters of

440

441

442

443

444

445

446

447

448

449

450

451

452

453

454

455

456

457

458

459

460

461

462

463

464

465

466

467

468

469

470

471

472

473

474

475

476

477

different sources by analysing the nitrogen and oxygen isotopic ratio, Environmental Sciences: Processes and Impacts, 15(4), 751-759. DOI 10.1039/c3em30920g

Lee H.W., Lee Y.S., Kim J., Lim K.J., Choi J.H. (2019), Contribution of internal nutrients loading on the water quality of a reservoir, Water, 11, 1409. DOI 10.3390/w11071409

Loh P.S., Molot L.A., Nürnberg G.K., Watson S.B., Ginn B. (2013), Evaluating relationships between sediment chemistry and anoxic phosphorus and iron release across three different water bodies, Inland Waters 3(1), 105-118. DOI 10.5268/IW-3.1.533

Madeyski M., Michalec B., Tarnawski M. (2008), Silting of small water reservoirs and quality of sediments (in Polish), Infrastructure and ecology of rural areas, Polish Academy of Science, Commission of Technical Infrastructure, Kraków, pp 1-77.

Małecki Z. (2005), Water Protection (in Polish),. EkoTechnika, 4(36), 8-10.

Markowski M., Kwidzińska M. (2015), Types of geoecosystems of the lobelia lakes of the tricity area, Quaestiones Geographicae, 34(1), 15-25. DOI 10.1515/quageo-2015-0002

Matisoff G., Kaltenberg E.M., Steely R.L., Hummel S.K., Seo J., Gibbons K.J., Bridgeman T.B., Seo Y., Behbahani M., James W.F., Johnson L.T., Doan P., Dittrich M., Evans M.A., Chaffin J.D. (2016), Internal loading of phosphorus in western Lake Erie, Journal of Great Lakes Research, 42, 775-788. DOI 10.1016/j.jglr.2016.04.004

Michalec B., Tarnawski M. (2008), The influence of small water reservoir operational changes on capacity reduction, Environment Protection Engineering, 34(3), 117-124.

Mulligan M., van Soesbergen A., Sáenz L. (2020), GOODD, a global dataset of more than 38,000 georeferenced dams, SCIENTIFIC DATA, 7(31). DOI 10.1038/s41597-020-0362-5

Nikolai SJ., Dzialowski AR. (2014), Effects of internal phosphorus loading on nutrient limitation in a eutrophic reservoir, Limnologica, 49, 33-41. DOI 10.1016/j.limno.2014.08.005

North R.L., Johansson J., Vandergucht D., Doig L.E., Liber K., Lindenschmidt K.-E., Baulch H., Hudson J.J. (2015), Evidence for internal phosphorus loading in a large prairie reservoir (Lake Diefenbaker, Saskatchewan), Journal of Great Lakes Research, 41(2), 91-99. DOI 10.1016/j.jglr.2015.07.003

Nürnberg G.K., LaZerte B.D., Loh P.S., Molot L.A. (2013), Quantification of internal phosphorus load in large, partially polymictic and mesotrophic Lake Simcoe, Ontario, Journal of Great Lakes Research, 39, 271-279. DOI 10.1016/j.jglr.2013.03.017

Orihel D.M., Schindler D.W., Ballard N.C., Graham M.D., O'Connell D.W., Wilson L.R., Vinebrooke R.D. (2015), The "nutrient pump:" Iron-poor sediments fuel low nitrogen-to phosphorus ratios and cyanobacterial blooms in polymictic lakes. Limnology and Oceanography, 60, 856-871. DOI 10.1002/lno.10076

Pardo P., Rauret G., Lopez-Sanchez J.F. (2004), Shortened screening method for phosphorus fractionation in sediments. A complementary approach to the standards, measurements and testing harmonized protocol, Analytica Chimica Acta, 508, 201-206. DOI 10.1016/j.aca.2003.11.005

Peer] reviewing PDF | (2020:01:44688:1:0:NEW 27 Apr 2020) 
478 Paytan A., Roberts K., Watson S., Peek S., Chuang P.Ch., Defforey D., Kendall C. (2017),

479

480

481

482

483

484

485

486

487

488

489

490

491

492

493

494

495

496

497

498

499

500

501

502

503

504

505

Internal loading of phosphate in Lake Erie Central Basin, Science of the Total Environment 579, 1356-1365. DOI 10.1016/j.scitotenv.2016.11.133

Report RP (2016), Report on the implementation of the research project no 2011/03/B/ST10/04998 financed by the Polish National Science Center (in Polish).

Ruban V., Lopez-Sanchez J.F., Pardo P., Rauret G., Muntau H., Quevauviller P. (2001), Development of a harmonized phosphorus extraction procedure and certification of a sediment reference material, Journal of Environmental Monitoring, 3, 121-125. DOI: $10.1039 / \mathrm{B} 005672 \mathrm{~N}$

Sobczyński T. (2009), Phosphorus release from lake bottom sediments affected by abiotic factors, Archives of Environmental Protection, 35(2), 67-73.

Tammeorg O., Horppila J., Tammeorg P., Haldna M., Niemistö J. (2016), Internal phosphorus loading across a cascade of three eutrophic basins: A synthesis of short- and long-term studies, Science of the Total Environment, 572, 943-954. DOI

10.1016/j.scitotenv.2016.07.224

Wiatkowski M., Rosik-Dulewska Cz. (2016), Hydrological and hydraulic conditions of prereservoir construction in the back of the Słup reservoir (in Polish), Rocznik Ochrona Środowiska, 18, 468-479.

Wiśniewski R. (1999), Attempts of phosphate inactivation in bottom sediments and inhibition of cyanobacterial blooms in the Łasiński Lake as potential reclamation methods (in Polish), In, Tomaszek JA (ed), Proceedings of 1st Conference, Development in Environmental Engineering, Oficyna Wydawnicza PRz, Rzeszów, pp 189-202.

Wojciechowska E., Gajewska M., Ostojski A. (2017), Reliability of nitrogen removal processes in multistage treatment wetlands receiving high-strength wastewater, Ecological Engineering, 98, 365-371. DOI 10.1016/j.ecoleng.2016.07.006

Wojtkowska M. (2013), Migration and forms of metals in bottom sediments of Czerniakowskie Lake. Bulletin of Environmental Contamination and Toxicology, 90(2), 165-169. DOI 10.1007/s00128-012-0881-7 


\section{Table $\mathbf{1}$ (on next page)}

Assessment of natural resilience to degradation of the Rzeszów Reservoir, based on (Bajkiewicz - Grabowska, 1987, 2010). 
1

\begin{tabular}{|c|c|c|}
\hline Parameters & $\begin{array}{c}\text { Obtained } \\
\text { for Rzeszów } \\
\text { Reservoir }\end{array}$ & Amount \\
\hline Average depth [m] & 0.6 & 3 \\
\hline $\begin{array}{l}\text { Ratio of reservoir capacity } \\
{\left[{ }^{\prime} 000 \mathrm{~m}^{3}\right] \text { to length of }} \\
\text { shoreline }[\mathrm{m}]\end{array}$ & 0.12 & 3 \\
\hline $\begin{array}{l}\text { Participation of the water } \\
\text { stratification [\%] }\end{array}$ & $<20$ & 3 \\
\hline $\begin{array}{l}\text { Ratio of the active sediment } \\
\text { layer surface }\left[\mathrm{m}^{2}\right] \text { to volume of } \\
\text { epilimnion }\left[\mathrm{m}^{3}\right]\end{array}$ & 0.46 & 3 \\
\hline Intensity of water exchange & 456 & 0 \\
\hline Schindler's ratio* $\left[\mathrm{m}^{2} \cdot \mathrm{m}^{-3}\right]$ & 1873 & 3 \\
\hline Average value of points & \multicolumn{2}{|l|}{2.5} \\
\hline $\begin{array}{l}\text { Resilience category of the } \\
\text { reservoir }\end{array}$ & \multicolumn{2}{|l|}{ IV } \\
\hline
\end{tabular}

2 * Ratio of the total area of the catchment and the reservoir to the volume of reservoir. 


\section{Table 2 (on next page)}

Assessment of the Rzeszów Reservoir catchment as a supplier of biogenic and organic matter, based on (Bajkiewicz - Grabowska, 1987, 2010). 
1

\begin{tabular}{|l|c|c|}
\hline Parameters & $\begin{array}{c}\text { Obtained for } \\
\text { Rzeszów } \\
\text { Reservoir }\end{array}$ & Amount \\
\hline Ohle's coefficient* & 4041 & 3 \\
\hline Balance type of lake & flow-through & 3 \\
\hline $\begin{array}{l}\text { Average slope in the } \\
\text { catchment [\%] }\end{array}$ & 13.8 & 2 \\
\hline $\begin{array}{l}\text { Geological structure } \\
\text { of the catchment }\end{array}$ & sandy-clayey & 1 \\
\hline $\begin{array}{l}\text { Usage of the } \\
\text { catchment }\end{array}$ & $\begin{array}{c}\text { pasture - } \\
\text { agricultural with } \\
\text { buildings }\end{array}$ & 3 \\
\hline $\begin{array}{l}\text { Density of river } \\
\text { network [km•km }{ }^{-2} \text { ] }\end{array}$ & 0.41 & 0 \\
\hline $\begin{array}{l}\text { Contribution of } \\
\text { endorheic areas [\%] }\end{array}$ & $<20$ & 3 \\
\hline $\begin{array}{l}\text { Average value of } \\
\text { points }\end{array}$ & \multicolumn{2}{|c|}{2.14} \\
\hline $\begin{array}{l}\text { Susceptibility group of } \\
\text { the catchment }\end{array}$ & 4 \\
\hline
\end{tabular}

$2 *$ Ratio of the total catchment area to the reservoir area. 


\section{Table 3(on next page)}

Carlson trophic index values (TSI $\left.\right|_{\text {TP, }}$ TSI $_{\text {Chla }}$ ) and selected physico-chemical parameters of water in the Rzeszów Reservoir (E-eutrophy, H-hypertrophy). 
1

\begin{tabular}{|c|c|c|c|c|c|c|c|}
\hline \multirow{2}{*}{$\begin{array}{l}\mathscr{0} \\
\stackrel{0}{0} \\
\stackrel{0}{0}\end{array}$} & \multirow{2}{*}{$n=9$} & $\mathbf{T}_{\mathrm{w}}$ & $\mathbf{T N}$ & TP & \multirow{2}{*}{$\begin{array}{c}\text { Chla } \\
{\left[\mu \mathrm{g} \cdot \mathrm{dm}^{-3}\right]}\end{array}$} & \multirow[t]{2}{*}{$\mathbf{T S I}_{\mathbf{T P}}$} & \multirow[t]{2}{*}{$\mathbf{T S I}_{\text {Chla }}$} \\
\hline & & {$\left[{ }^{\circ} \mathrm{C}\right]$} & \multicolumn{2}{|c|}{$\left[\mathrm{mg} \cdot \mathrm{dm}^{-3}\right]$} & & & \\
\hline \multirow{5}{*}{1} & Average & 19.3 & 1.48 & 0.168 & 27.1 & 80 & 66 \\
\hline & Minim. & 13.0 & 0.88 & 0.095 & 1.1 & & \\
\hline & Max & 26.1 & 2.36 & 0.268 & 71.6 & & \\
\hline & Std. Dev. & 4.2 & 0.4 & 0.06 & 27.9 & 5 & 8 \\
\hline & $\begin{array}{c}\text { Trophic } \\
\text { state }\end{array}$ & & & & & $\mathrm{H}$ & $\mathrm{E}$ \\
\hline \multirow{5}{*}{2} & Average & 19.4 & 1.36 & 0.167 & 26.6 & 78 & 66 \\
\hline & Minim. & 13.1 & 0.82 & 0.105 & 3.7 & & \\
\hline & Max & 26.1 & 1.75 & 0.282 & 93.5 & & \\
\hline & Std. Dev. & 4.3 & 0.3 & 0.06 & 28 & 4 & 7 \\
\hline & $\begin{array}{c}\text { Trophic } \\
\text { status }\end{array}$ & & & & & $\mathrm{H}$ & $\mathrm{E}$ \\
\hline \multirow{5}{*}{3} & Average & 19.3 & 1.54 & 0.177 & 37.0 & 80 & 69 \\
\hline & Minim. & 13.2 & 0.77 & 0.096 & 2.5 & & \\
\hline & Max & 26.1 & 2.43 & 0.343 & 161.7 & & \\
\hline & Std. Dev. & 4.6 & 0.5 & 0.07 & 49.5 & 5 & 9 \\
\hline & $\begin{array}{c}\text { Trophic } \\
\text { state }\end{array}$ & & & & & $\mathrm{H}$ & $\mathrm{E}$ \\
\hline \multirow{3}{*}{ 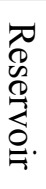 } & Average & 19.3 & 1.46 & 0.171 & 30.2 & 80 & 67 \\
\hline & Std. Dev. & 4.2 & 0.4 & 0.06 & 36 & 5 & 8 \\
\hline & $\begin{array}{l}\text { Trophic } \\
\text { state }\end{array}$ & & & & & $\mathrm{H}$ & $\mathrm{E}$ \\
\hline
\end{tabular}


Table 4 (on next page)

The determined EPC- 0 values $\left[\mathrm{mgP} \bullet \mathrm{dm}^{-3}\right]$ for the bottom sediments of the Rzeszów Reservoirs ( $r$ - correlation coefficient). 
1

\begin{tabular}{|c|c|c|c|c|c|c|}
\hline \multirow[b]{2}{*}{ Site no. } & \multicolumn{3}{|c|}{ Aerobic conditions } & \multicolumn{3}{|c|}{ Anoxic conditions } \\
\hline & 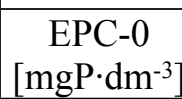 & $\mathrm{r}$ & $\mathrm{n}$ & $\begin{array}{c}\text { EPC-0 } \\
{\left[\mathrm{mgP} \cdot \mathrm{dm}^{-3}\right]}\end{array}$ & $\mathrm{r}$ & $\mathrm{n}$ \\
\hline 1 & 0.071 & 0.998 & 6 & 0.782 & 0.972 & 5 \\
\hline 2 & 0.073 & 0.996 & 6 & 0.529 & 0.956 & 6 \\
\hline 3 & 0.082 & 0.999 & 6 & 0.776 & 0.943 & 6 \\
\hline
\end{tabular}

2

3 


\section{Table 5 (on next page)}

Content of total phosphorus, organic matter (OM), calcium, iron, manganese, aluminum, water $\left(\mathrm{W}_{0}\right)$ and phosphorus fractions contribution [\%] in TP in the bottom sediments of the Rzeszów Reservoir. 
1

2

\begin{tabular}{|c|c|c|c|c|c|c|c|c|c|c|c|}
\hline \multirow{2}{*}{ Site no. } & \multirow{2}{*}{$\mathrm{n}=9$} & $\mathbf{C a}$ & $\mathbf{F e}$ & Mn & Al & TP & NAIP & AP & OP & OM & $\mathbf{W}_{0}$ \\
\hline & & \multicolumn{5}{|c|}{$\left[\mathrm{mg} \cdot \mathrm{g}^{-1}\right.$ of d.w. $]$} & \multicolumn{5}{|c|}{$[\%]$} \\
\hline \multirow{4}{*}{1} & Average & 25.3 & 22.2 & 0.598 & 27.4 & 0.829 & 43.3 & 33.3 & 21.7 & 6.89 & 52.7 \\
\hline & Minim. & 20.2 & 19.1 & 0.466 & 22.5 & 0.668 & 37.0 & 28.1 & 19.1 & 5.84 & 44.5 \\
\hline & Max & 29.7 & 29.6 & 0.697 & 33.9 & 1.320 & 48.9 & 38.4 & 25.2 & 9.07 & 60.8 \\
\hline & Std. Dev. & 3.2 & 3.2 & 0.1 & 3.7 & 0.19 & 4.1 & 2.8 & 2.1 & 1.2 & 5.2 \\
\hline \multirow{4}{*}{2} & Average & 27.4 & 24.0 & 0.652 & 29.8 & 0.846 & 41.3 & 33.7 & 23.2 & 7.97 & 54.9 \\
\hline & Minim. & 19.9 & 19.1 & 0.487 & 23.8 & 0.664 & 37.5 & 28.5 & 18.8 & 5.28 & 45.9 \\
\hline & Max & 40.3 & 27.0 & 0.851 & 33.2 & 1.022 & 46.6 & 39.1 & 28.9 & 10.4 & 61.3 \\
\hline & Std. Dev. & 6.4 & 2.5 & 0.1 & 3.1 & 0.13 & 2.9 & 3.3 & 3.6 & 1.8 & 5.5 \\
\hline \multirow{4}{*}{3} & Average & 25.9 & 21.0 & 0.541 & 25.6 & 0.711 & 43.0 & 35.8 & 20.0 & 6.91 & 48.6 \\
\hline & Minim. & 23.1 & 18.0 & 0.436 & 23.2 & 0.611 & 37.2 & 29.7 & 16.3 & 5.35 & 41.7 \\
\hline & Max & 27.6 & 23.8 & 0.665 & 27.8 & 0.863 & 50.4 & 41.7 & 23.2 & 8.40 & 57.3 \\
\hline & Std. Dev. & 1.5 & 1.8 & 0.1 & 1.3 & 0.08 & 5.0 & 3.6 & 2.2 & 0.9 & 5.0 \\
\hline \multirow{2}{*}{ Reservoir } & Average & 26.2 & 22.4 & 0.597 & 27.6 & 0.795 & 42.5 & 34.3 & 21.6 & 7.26 & 52.1 \\
\hline & Std. Dev. & 4.1 & 2.8 & 0.1 & 3.3 & 0.15 & 4.0 & 3.3 & 2.9 & 1.4 & 5.7 \\
\hline
\end{tabular}

3 
Table 6(on next page)

Estimated value of the internal load in the Rzeszów Reservoir. 
1

\begin{tabular}{|l|cc|}
\hline \multirow{2}{*}{ Site no. } & \multicolumn{2}{|c|}{$\begin{array}{c}\text { Internal load } \\
{\left[\mathrm{mgP} \cdot \mathrm{m}^{-2} \mathrm{~d}^{-1}\right]}\end{array}$} \\
\cline { 2 - 3 } & $\begin{array}{c}\text { Aerobic } \\
\text { conditions }\end{array}$ & $\begin{array}{c}\text { Anoxic } \\
\text { conditions }\end{array}$ \\
\hline 1 & 58 & 662 \\
2 & 86 & 688 \\
3 & 107 & 1284 \\
Average & $\mathbf{8 4}$ & $\mathbf{8 7 8}$ \\
\hline
\end{tabular}

2

3

4

5

6

7

8 
Figure 1

Localization of the Rzeszów Reservoir with its parameters and sampling stations.

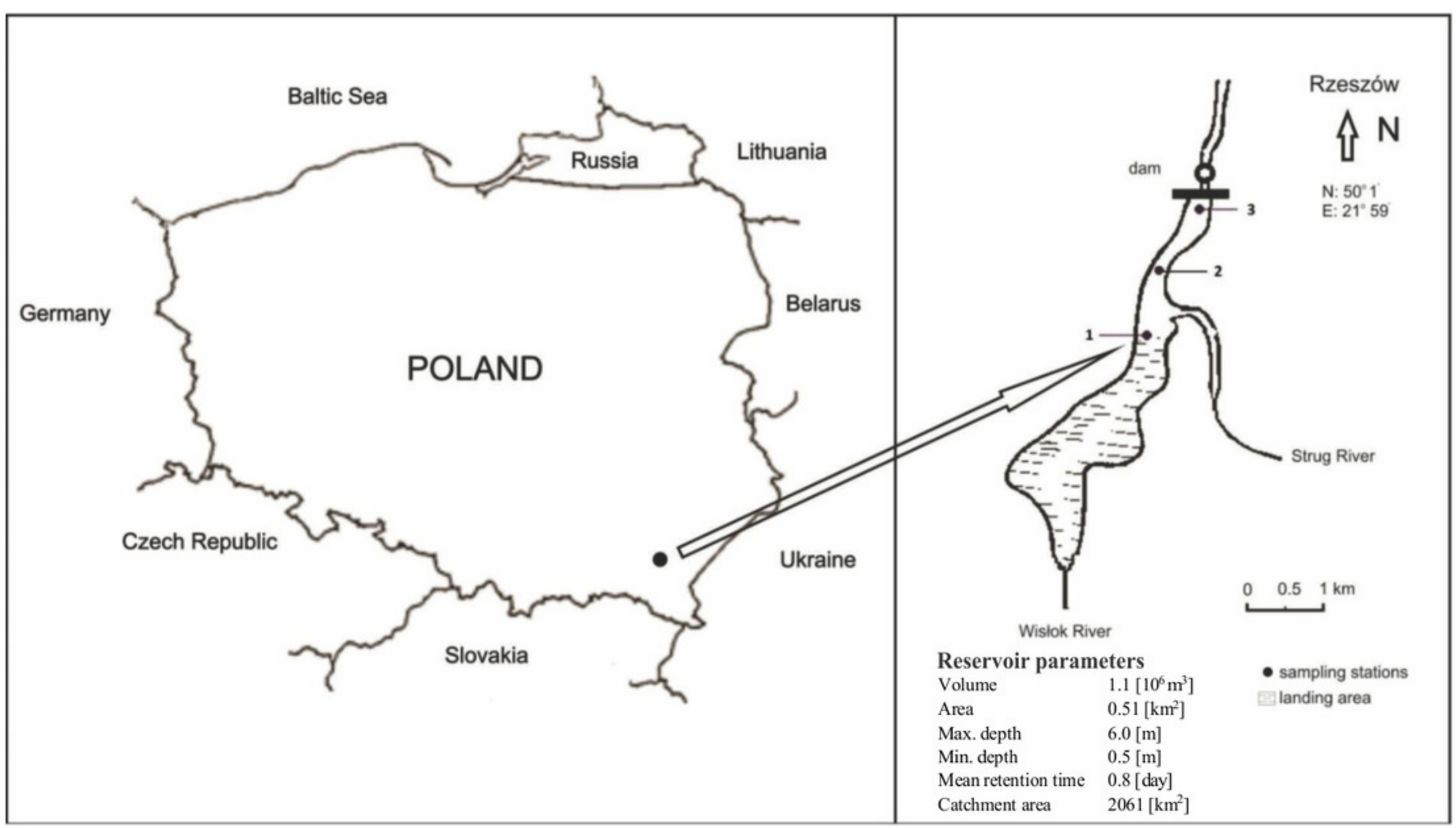


Figure 2

Variability of oxygen content [\%] (A), pH (B) and Chla concentration (C) in the water of the Rzeszów Reservoir. 

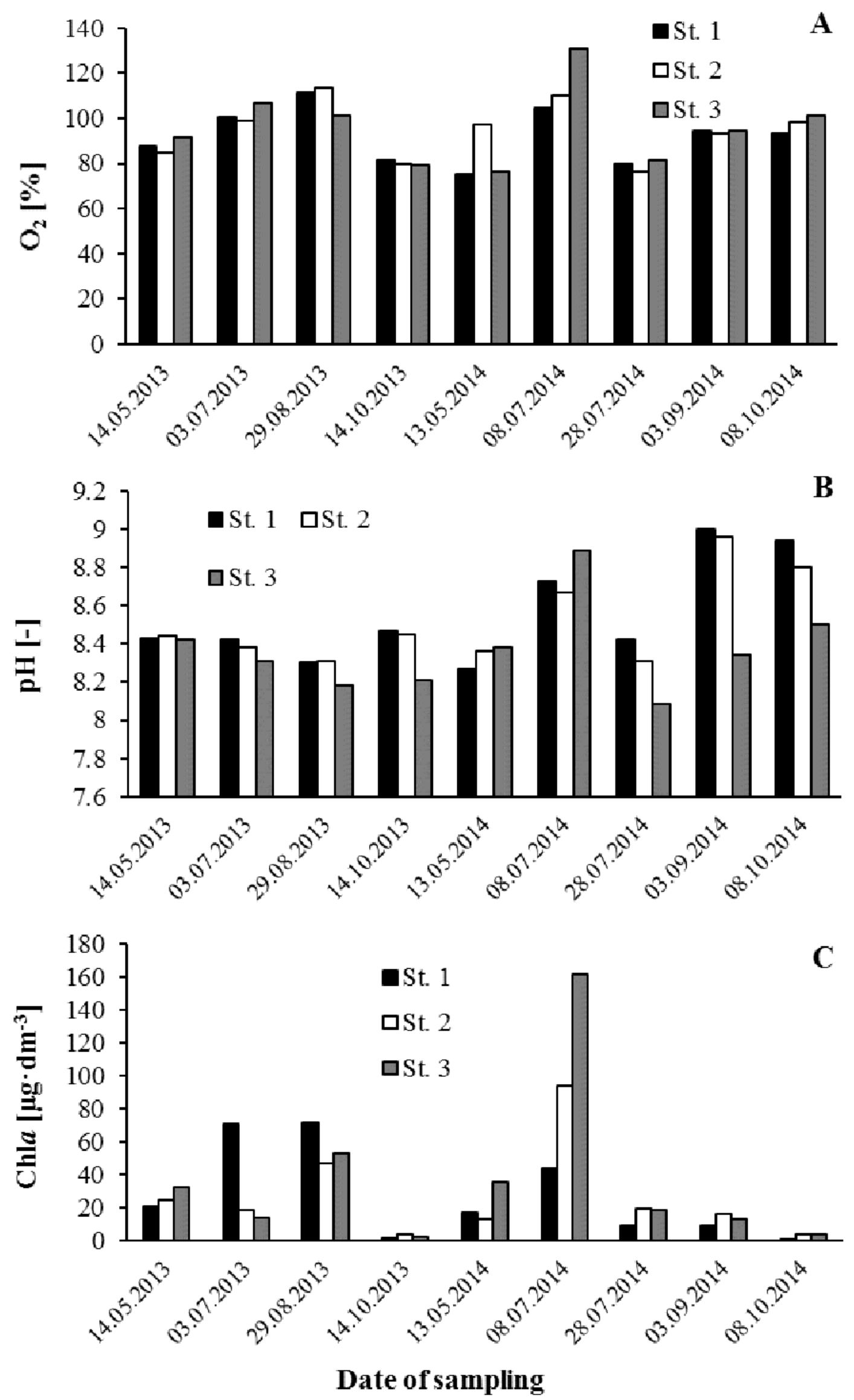
Figure 3

Variability of phosphate phosphorus concentrations $\left[\mathrm{mgP} \cdot \mathrm{dm}^{-3}\right]$ in the water of the Rzeszów Reservoir in relation to EPC-0 values determined for sediments in aerobic conditions.

A - site $1 ; \mathrm{B}-2 ; \mathrm{C}-3$. 

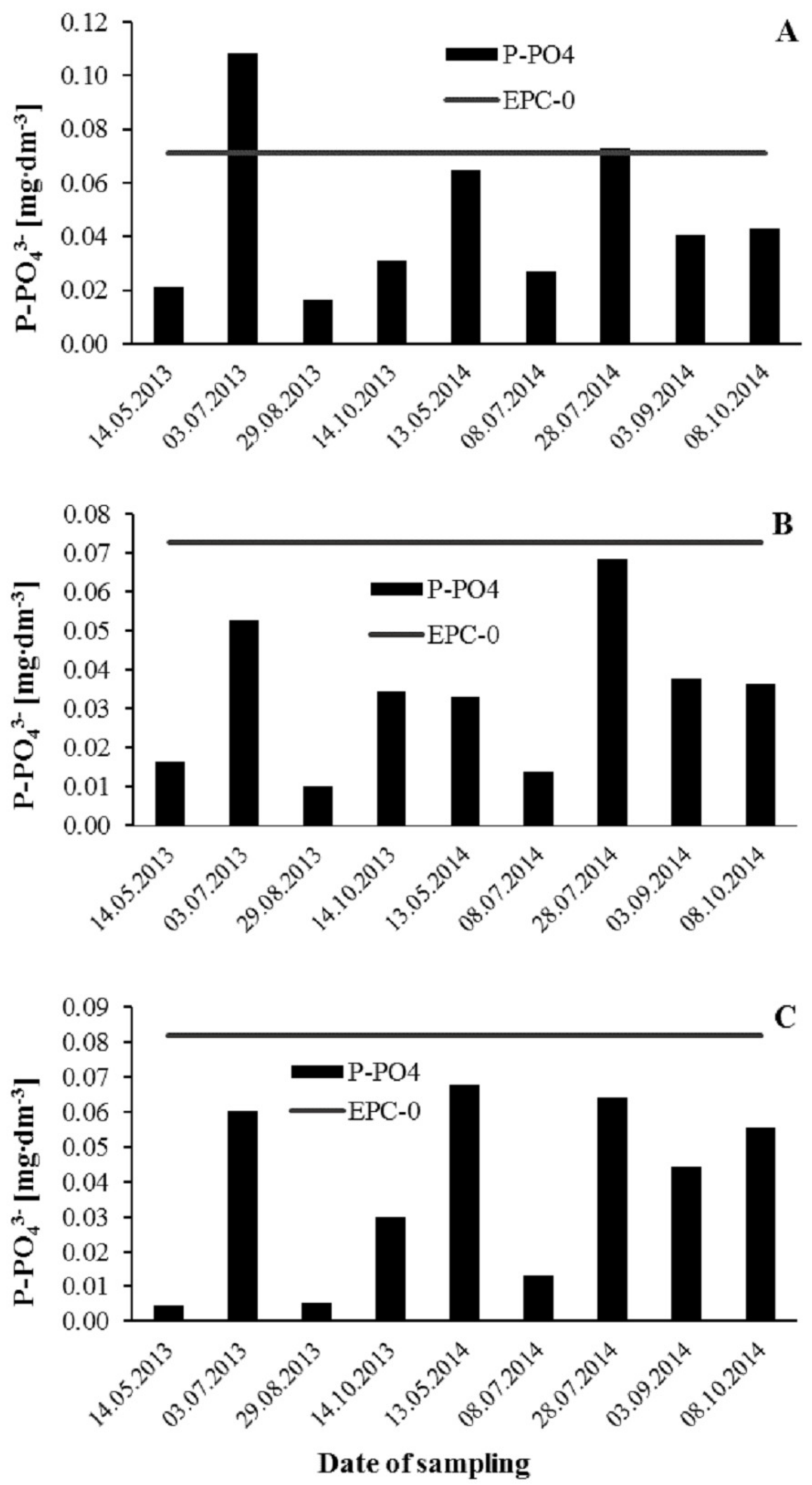